\title{
IDENTIFICATION OF PUMICE AND VOLCANIC ASH FROM ARCHAEOLOGICAL SITES IN THE EASTERN MEDITERRANEAN REGION USING CHEMICAL FINGERPRINTING
}

\author{
By Heinz Huber, ${ }^{\mathrm{a}, \mathrm{b}}$ Max Bichler, ${ }^{\mathrm{b}}$ Andreas Musilek ${ }^{\mathrm{b}}$
}

\section{INTRODUCTION}

The volcanic layer of the "Minoan" eruption of the Thera volcano between 1450 and 1650 B.C. is a clear time marker in the stratigraphy of the surrounding area. Therefore, the general idea of this study was to settle the volcanic products of this major eruption, which lasted only a few days, within the relative archaeological chronologies of the Eastern Mediterranean region in correlation to its different time frames. Although the date of the eruption is still object of intense debates, ${ }^{1}$ the eruption products can be used as tangible evidence for contemporaneity or at least post-eruption dating of the respective strata wherever found within well-defined stratigraphies of an archaeological site.

The majority of the erupted material consists of chemically rather homogeneous pumice and pumiceous flow deposits, the so-called "Minoan tuff" or "Oberer Bimsstein" (Bo, upper pumice ${ }^{2}$ ). Gener-

\footnotetext{
a Institute of Geophysics and Planetary Physics, University of California Los Angeles, 405 Hilgard Avenue, Los Angeles, CA 90095-1361, USA.

b Atominstitut der österreichischen Universitäten, Department of Radiochemistry, Technical University Vienna, Stadionallee 2, 1020 Vienna, Austria.

1 Manning S.W. (1999), A Test of Time - The Volcano of Thera and the chronology and history of the Aegean and east Mediterranean in the mid second millennium $B C$, Oxbow books, Oxford and Oakville.

2 Vitaliano C.J., Fout J.S., Vitaliano D.B. (1978), Petrochemical study of the Tephra sequence exposed in the Phira Quarry, Thera, in: C. Doumas (ed.), Thera and the Aegaean World 1, London, 203-215; Vitaliano C.J. TAYLOR S.R., Norman M.D., McCulloch M.T., Nicholls I.A. (1990), Ash layers of the Thera Volcanic Series: Stratigraphy, Petrology and Geochemistry, in: HARDY D.A., Renfrew A.C. (eds.), Thera and the Aegean World III, London, 53-78; Francaviglia V., Di Sabatino B. (1990), Statistical Study on Santorini Pumicefalls, in: HARDY D.A., Renfrew A.C. (eds.), Thera and the Aegean World III, London, 29-52; Druitt T.H., Edwards L., Mellors R.M., Pyle D.M., Sparks R.S.J., Lanphere M., Davies M., BARriero B. (1999), Santorini Volcano Geological Society Special Publications, Geological Society of London 19, 165 pp; Sparks R., Wilson C. (1990), The Minoan deposits: a review of their characteristics and interpretation, in:
}

ally, the term tephra designates all fragmental volcanic ejecta produced during an eruption. The volume estimations for the tephra output of the Minoan eruption range from 16 to $35 \mathrm{~km}^{3}$ of dense rock equivalent. ${ }^{3}$ The impact on the contemporary civilizations is evident and alluvial pumice as well as direct fallout from the eruption cloud is reported from several sites on Greek islands and Asia Minor (see e.g., ${ }^{4}$ and references therein). The fallout formed a synchronous layer of volcanic ash (tephra with grain size $\leq 2 \mathrm{~mm}$ ) that can be used directly as a datum line. Provided a reliable identification, it can be used for chronology wherever found in primary deposits. Pumice, on the contrary, floats on water and was transported over large distances all over the Eastern Mediterranean region due to marine currents and wind. ${ }^{5}$ It can be assumed that within weeks after the eruption large amounts of pumice were accumulated along the shorelines. Pumice is a quite useful abrasive which has been collected and traded

Hardy D.A., Renfrew A.C. (eds.), Thera and the Aegean World III, London, 89-99.

3 Sigurdsson H., Carey S., Devine J.D. (1990), Assessment of Mass, Dynamics and Environmental Effects of the Minoan eruption of Santorini volcano, in: HARDY D.A., RENFrew A.C. (eds.), Thera and the Aegean World III, London, 100-112; PyLE D.M. (1990) New estimates for the volume of the Minoan eruption, in: HARDY D.A., RENFREW A.C. (eds.), Thera and the Aegean World II, London, 113-120.

4 Peltz C., Schmid P., Bichler M. (1999), INAA of Aegean pumices for the classification of archaeological findings, Journal of Radioanalytical and Nuclear Chemistry 242/ 2, 361; Pearce N.J.G., Eastwood W.J., Westgate J.A., Perkins W.T. (2002), Trace-element composition of single glass shards in distal Minoan tephra from SW Turkey, Journal of the Geological Society London 159, 545-556.

5 Bichler M., Egger H., Preisinger A., Ritter D., Stastny P. (1997), NAA of the 'Minoan pumice' at Thera and comparsion to alluvial pumice deposits in the Eastern Mediterranean region, Journal of Radioanalytical and Nuclear Chemistry 224, 7-14; WARREN P.M., PuChelt H. (1990), Stratified Pumice from Bronze Age Knossos, in: Hardy D.A., Renfrew A.C. (eds.) Thera and the Aegean World III, 3, 71-81. 


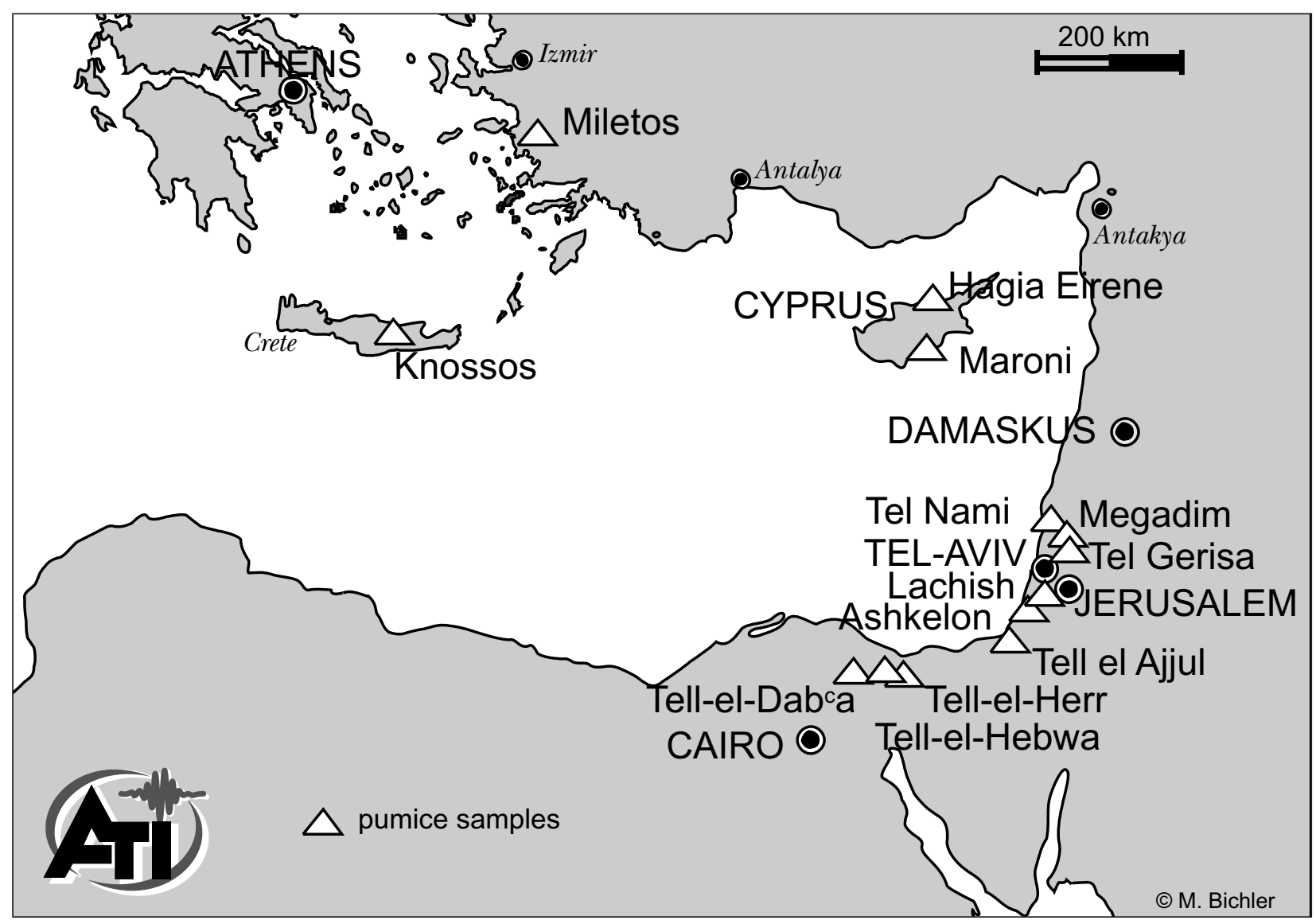

Fig. 1 Geographical distribution of pumice samples found in archaeological excavations of the Eastern Mediterranean that were included in this study

since prehistoric times. The applicability for chronological purposes has been checked in earlier studies by demonstrating that the "Minoan" pumice is sufficiently homogeneous and can be distinguished from the numerous other Aegean pumice sources by comparing normalized trace element distribution patterns ("chemical fingerprinting"). ${ }^{6}$ Additionally, these studies have shown that instrumental neutron activation analysis (INAA) is a perfectly suitable technique to identify such material.

Nevertheless, for the identification of tephra deposits in greater distance to the volcano a chemi- cally relevant effect has to be considered. The erupted material consists mainly of highly vesicular silicate glass (pumice) with a certain percentage of crystals having formed during melt ascent (e.g., pyroxene, quartz, feldspar, titanomagnetite). Several elements are enriched in these mostly sub-mm sized crystals, which numerically decrease with growing distance from the volcano due to separation by gravity. ${ }^{7}$ Previous studies from our working group ${ }^{8}$ showed significant differences in the compositions between bulk pumice and the pure glass fraction. The occurrence of Minoan tephra deposited direct-

6 Bichler M., Egger H., Preisinger A., Ritter D., Stastny P. (1997), NAA of the 'Minoan pumice' at Thera and comparsion to alluvial pumice deposits in the Eastern Mediterranean region, Journal of Radioanalytical and Nuclear Chemistry 224, 7-14; Bichler M., Peltz C., SAMinger S., Exler M. (2003), Aegean Tephra - an analytical approach to a controversy about chronology, Egypt and the Levant 12, 55-70.

\footnotetext{
7 Williams H., McBirney A.R. (1979), Volcanology, Freeman, Cooper \&Co, San Francisco, USA, 138ff.

8 Schmid P., Peltz C., Hammer V.M.F., Halwax E., Ntaflos T., Nagl P., Bichler M. (2000), Separation and Analysis of Theran Volcanic Glass by INAA, XRF and EPMA, Mikrochimica Acta 133, 143-149.
} 
ly from the eruption cloud is not restricted to the Aegean region. It has also been found in lake sediments from Köycegiz, Gölcük Gölü, Gölhisar Gölü (Turkey) and even in deep-sea cores from the Black Sea. ${ }^{9}$ The estimated orientation and extent of the tephra layer differs greatly depending which types of deposits (e.g. lacustrine and continental deposits, deep-sea drill cores) are considered. This is due to the difficulty to decide whether deep-sea tephra layers have been produced by fallout from the eruption cloud or if there is a major contribution by sunken, fragmented, and compacted pumice. The amount of this contribution is governed by the direction of the marine currents and the time span until the pumice starts to sink. Experiments and observations have shown that this can last for months ${ }^{10}$ and therefore a significant amount can be expected even in areas where actually no eruption cloud fallout has been deposited.

\section{Samples and ANalytical TechniQues}

In this study 286 samples of archaeologically stratified pumice collected in excavations at Tell el-Dabca (Egypt), Sinai, Tel Nami, Tel Gerisa, Ashkelon, and Megadim (all Israel), Miletos (Turkey), and Knossos (Crete) were identified due to their mineralogical composition and by chemical fingerprinting. For an overview on the geographical situation see Fig. 1. The pumice pieces vary in size between one and 15 $\mathrm{cm}$ in diameter, and are whitish to brown in color mostly with abundant crystals of feldspar, biotite, quartz, or ore minerals. The tephra layer found in the excavation site of Iasos, Turkey (Fig. 2) was analyzed on the elemental distribution within the layer.

\section{Sample preparation}

Each archaeological sample was treated as follows: after thorough surface cleaning with distilled water in an ultrasonic bath and the microscopical investi-

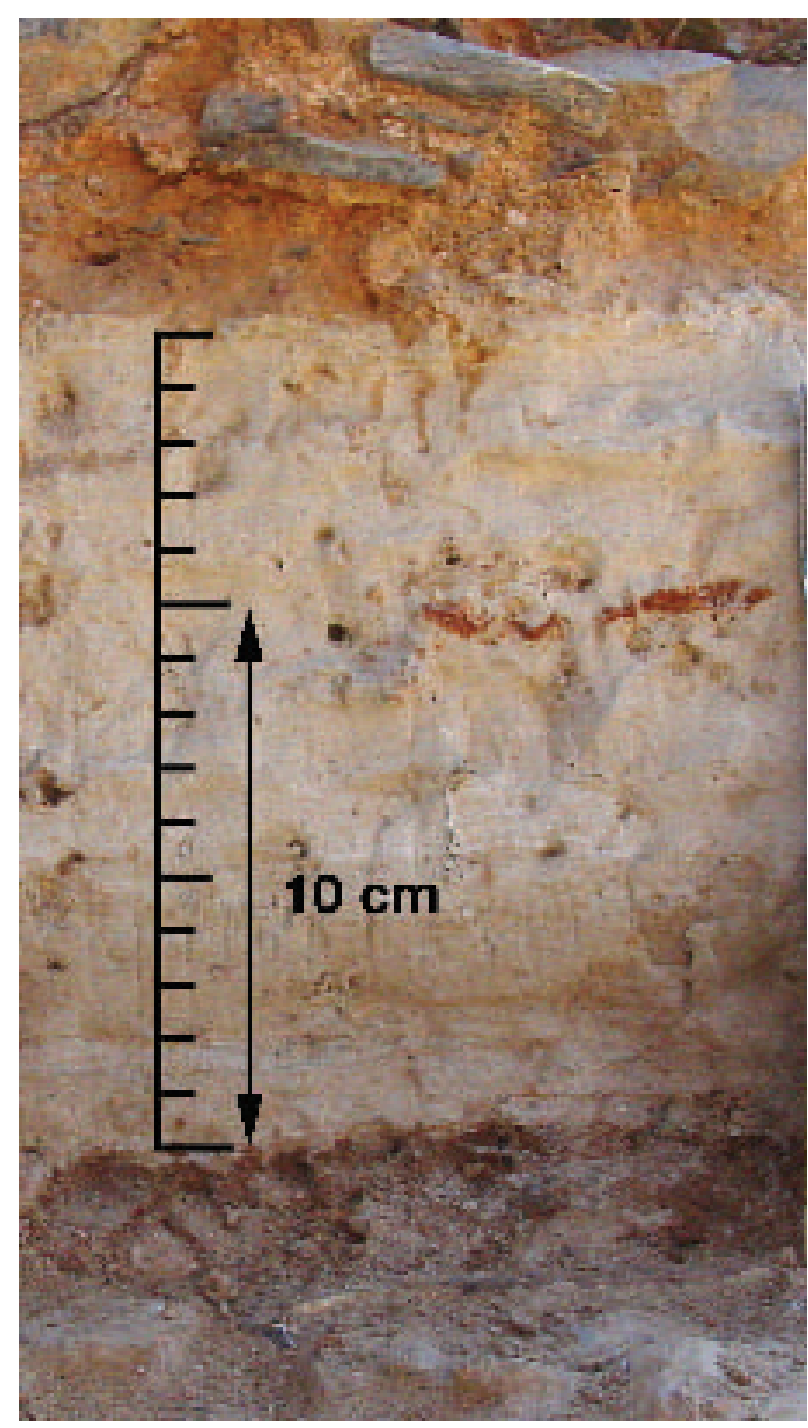

Fig. 2 Overview of the tephra layer at Iasos, Turkey. This layer was found below a roman pavement

gation, about $1 \mathrm{~g}$ (or more, if available) of each sample was crushed exclusively with polyethylene (PE) tools and transferred to polypropylene (PP) beakers to avoid any contamination. Drying for about 90

\footnotetext{
9 VAn Zeist V., Woldoring H., STAPERT D. (1975), Late Quaternary vegetation and climate of southwestern Turkey, Palaeohistoria 17 55-143; Sullivan D.G. (1988), Discovery of Santorini Minoan Tephra in Western Turkey, Nature 333, 552-554; Guichard F., Carey S., Arthur M.A., SigURdsson H., ARnold M. (1993), Tephra from the Minoan eruption of Santorini in sediments of the Black Sea, Nature 363, 610-612; Keller J. (1980), Prehistoric pumice tephra on Aegean islands, in: C. Doumas (ed.), Thera and the Aegean World II, 49-56; Vinci A. (1985), Distribution and chemical composition of tephra layers from Eastern Mediterranean abyssal sediments, Marine
}

Geology 64, 143-155; WATKINS N.D., SPARKS R.S.J., Sigurdsson H., Huang T.C., Federman A., Carey S., Ninkovich D. (1978), Volume and extent of the Minoan tephra layer from Santorini volcano: new evidence from deep-sea sediment cores, Nature 271, 122-126; Soles J.S., Davaras C. (1990), Theran ash in Minoan Crete: New excavations in Mochlos, in: Hardy D.A., Renfrew A.C. (eds.), Thera and the Aegean World III, 89-95.

10 Sutherland F.L. (1965), Dispersal of pumice supposedly from the 1962 South Sandwich Islands eruption on Southern Australian shores, Nature 207, 1332-1335. 
hours and homogenization by grinding in an agate mortar to grain sizes $<3$ micrometers were followed by additional drying to constant weight at $110^{\circ} \mathrm{C}$.

The tephra-layer from the excavation site at Iasos has an average thickness of about $16 \mathrm{~cm}$ over an accesible length of several meters. It was sampled in eight units of $2 \mathrm{~cm}$ each (see Fig. 2). To prepare the samples for instrumental neutron activation analysis (INAA) they were first dried for $12 \mathrm{~h}$ at $110^{\circ} \mathrm{C}$ then weighed and decarbonatized. To remove the carbonaceous compounds, $20 \mathrm{ml} \mathrm{HNO}_{3}$ conc. diluted with $80 \mathrm{ml}$ triple-distilled water were added to about $25 \mathrm{~g}$ of each dried sample in PP-beakers. A reduction of the fine-grained fraction $(<5$ micrometers) containing clay minerals was achieved by decanting the supernatant after one hour. This procedure was repeated at least three times until the solution was clear. Five reiterations were needed for the uppermost section of the layer because of its high contamination by organic material from the overlying soil. The residual solid fractions were dried in conical cups made of Teflon ${ }^{\mathrm{TM}}$ at $110^{\circ} \mathrm{C}$. The decanted fine-grained fractions were rinsed with tri-distilled water and acetone, and dried in Teflon ${ }^{\mathrm{TM}}$ cups, too. All fractions were re-weighed to determine the total amount of volatilized components. The fractions were named from bottom (Iasos 1) to top (Iasos 8) in the stratigraphic sequence.

\section{Optical microscopy}

The pumice samples were thoroughly examined under the binocular microscope to determine the amount and size of crystals (especially biotite) as well as the vesicularity and the texture of the glassy matrix.

The volcanic glass shards separated from the layer at Iasos were studied with a ZEISS Axiolab polarization-microscope with variable magnification up to 1000. From the separated material about $1 \mathrm{~mm}^{3}$ ( 5000 particles) was investigated by optical microscopy. These glass shards show characteristic shapes and appear as single grains as well as transparent aggregates. They are are optically isotropic, single shards clear, the aggregates with a more whitish appearance.

\section{Chemical fingerprinting}

For INAA about $150 \mathrm{mg}$ of each sample were sealed into Suprasil ${ }^{\mathrm{TM}}$ quartz glass vials. The samples were irradiated together with certified reference material for 100 hours in the KFKI-reactor of the Atomic Energy Research Institute, Budapest, Hungary, at a thermal neutron flux of $7 \times 10^{13} \mathrm{~cm}^{-2} \mathrm{~s}^{-1}$. The multielement standards used for the quantitative analysis were the CANMET reference soil SO1, NIST SRM 1633b Coal fly ash, BCR No. 142 light sandy soil, and MC rhyolite GBW 07113. The quartz sample vials were decontaminated and packed into polyethylene vials fitting the automatic sample changer facilities of the Atominstitut. After a decay time of 5 days, a first gamma-spectrum was measured to obtain the activities of the short and medium-lived activation products As-76, K-42, La-140, Lu-177, Na-24, Np-239 (U), and Sm-153. Three weeks later, a second measurement was started to detect the long-lived activation products Ba-131, Ce-141, Co-60, Cr-51, Cs-134, Eu-152, Fe-59, Hf-181, Lu-177, Nd-147, Pa-233 (Th), Rb-86, Sb-124, Sc-46, Ta-182, Tb-160, Yb-169, Zn-65, and Zr-95. The measuring times were $1800 \mathrm{~s}$ and $10000 \mathrm{~s}$, respectively. All samples were measured using an automatic sample changer with a fixed distance of $2 \mathrm{~cm}$ beside the detector. The whole analysis was performed with a $151 \mathrm{~cm}^{3}$ HPGe-detector (1.8 keV resolution at the $1332 \mathrm{keV}^{60} \mathrm{Co}$ peak), connected to a PC-based multichannel analyzer with preloaded filter and loss-free-counting system. ${ }^{11}$ Possible contributions by fission products to the Ce and $\mathrm{Nd}$ abundances were checked with the coal-fly-ash standard having a high U-content of $8.79 \mathrm{mg} / \mathrm{kg}$ resulting in no detectable influences.

\section{Results AND Discussion}

\section{Pumice}

The results of the chemical analysis are presented in Table 1. Normalizing these abundances to the average elemental abundances of Santorini Bo ("Minoan") pumice, a clear identification of the volcanic sources can be achieved (see Table 2). The results indicate that in the excavations pumice from the Southern Hellenic island arc (including Milos,
11 Westphal G.P. (1995), Digital Implementation of the Preloaded Filter Pulse Processor, Journal of Radioanalytical and Nuclear Chemistry 193, 81-88; WestPHAL G.P.
(1982), Real-time correction of counting losses in nuclear pulse spectroscopy, Journal of Radioanalytical and Nuclear Chemistry 70, 387-410. 
Santorini, Nisyros, Giali, Kos), from the Aeolian islands (Lipari, Italy), and from Central Anatolia was found. The associated volcanic eruption ages are given in Table 3. The elemental concentrations of some pumice samples (Tel Nami, Megadim) have been published ${ }^{12}$ previously, for a better overview they are added to Table 1.

The conformity of all elemental concentration data related to chemical fingerprinting is demonstrated for the pumice samples from Tell el Dabca, Series L in Fig. 3 a-f. The shaded areas represent the natural variation of the element concentrations found in the respective deposits (data from ${ }^{13}$ ). The samples can be clearly identified as "Minoan", from the greek islands Nisyros and Giali, or from Pre-Minoan eruptions of Santorini called Bu 2 and Cape Riva. Nevertheless, two samples could not be identified with the database actually available. Sample L-2 shows the same distribution pattern as three of the samples from Ashkelon (E80, E-146, E-174), but all of them can be distinguished from the Santorini Bo pumice.

Generally the patterns agree quite well with the natural variation ranges, nevertheless some exceptions have to be explained. The slight deviations are due to the very small quantities taken from the original pumice. The virtual enrichments in $\mathrm{Cr}$ and $\mathrm{Co}$ are most probably due to contamination during excavation work with steel tools, whereas the differences in $\mathrm{Sb}$ and As are due to the geochemical behavior (volatility) of these elements. Another possibility is the virtual dilution due to quartz grains in the samples. On the other hand only minor changes in composition due to leaching effects are found although glass hydration effects and strongly weathered rock surfaces were observed especially in the water-saturated sedimentary environment of Tell el Dabca. All these effects lead to misinterpretations in statistical programs, since they cannot consider the "robustness" of elements under all possible geochemical and environmental influences during pumice storage in the various archaeological sites. To confirm the identifications, binary trace element ratio plots represent a good means, ${ }^{13}$ such as the Eu versus $\mathrm{Ta}$ or $\mathrm{Eu} / \mathrm{Ta}$ versus $\mathrm{Ba} / \mathrm{Th}$ graph (Fig. 4). This graph is one example of an entire series of ele- ment ratio graphs especially designed to distinguish the different pumice-producing eruptions of the Santorini volcano. The samples from Tell el Dabca Series L plot very clear in the fields of Santorini Bo (Minoan Tuff), Bu (Lower pumice), and Cape Riva.

\section{Iasos tephra layer}

In Fig. 5 the trace element pattern normalized to Santorini Minoan Tuff (Bo, "oberer Bimsstein") is presented. The layer can be identified as Santorini Bo and shows a rather homogeneous composition. For the majority of the elements, depletions by a factor of 0.9 on the average can be observed. Exceptions are the elements As (mean enrichment factor 1.31), Cr (6.8), Co (1.18), Sb (1.44), and K (1.16). These enrichments are due to environmental contamination and were found at even higher levels in the separated fine-grained fraction containing the samples' clay mineral content (see Table 4; sample Iasos 1f).

Nevertheless, comparing the elements throughout the different layers (Fig. 6 a-d) the variations for most of the elements add up to the same trend. The layers with lowest carbonate abundances (e.g., $3 \& 7$ ) show the highest contents in all other elements determined and vice versa. Iasos 4 , the unit with $2^{\text {nd }}$-highest carbonate content is depleted in $\mathrm{Na}, \mathrm{K}, \mathrm{Fe}$, and most of the trace elements. The same phenomenon is found in layers 1 and 8 , which are highly contaminated by the over- and underlying soil, leading to depletions in all elements determined. In layer 4 , a contamination with carbonaceous muddy material mixed with silica could be the reason for the observed depletion of all elements determined.

On the contrary, layer 3 seems to be a very pure tephra-layer, such as layer 7 . Since these two layers are separated by the carbonate-rich layer 4 , the scenario seems to be as follows: Layer 1-3 represent the original tephra sequence, layer 4 shows the first intake of carbonaceous material from the environment, layer $5-7$ is slumped material washed in either during the deposition process or shortly afterwards.

Another possible explanation would be to assume that the minima of carbonaceous contamination (samples $1-3,5$ and 7 ) represent the first

12 Huber H., Bichler M. (2003), Geochemical correlation of archaeological sites using tephra from the Minoan eruption, Czechoslovak Journal of Physics 52, A47-A60.

13 Peltz C., Schmid P., Bichler M. (1999), inAA of Aegean pumices for the classification of archaeological findings, Journal of Radioanalytical and Nuclear Chemistry 242, 361-377. 
three phases of the Minoan eruption. However, this can be ruled out, since the chemical signature is typically for the first (Plinian) phase of this eruption, and the variations within all sub-units of the sequence are negligible compared to those found for the different phases of the Santorini eruption.

\section{Conclusions}

Pumice samples from diverse excavation sites throughout the whole Eastern Mediterranean region (Turkey to Egypt) have been identified using chemical fingerprinting and mineralogical investigations. Those samples that could not yet be identified can be clearly differentiated from Santorini Bo pumice and from all other sources already investigated in our research group. Samples taken during an excursion to Cappadocia (Central Anatolia, Turkey) in summer 2003 will significantly enlarge the analytical database and enhance our ability to identify pumice findings accordingly.

The tephra layer at Iasos is a good example for studying geochemical changes by post-depositional effects on such tephra falls. The modification started with the deposition and slumping of different sequences within the layer and was carried on by the infiltration of solutions bearing carbonate, silica, and other agents related to soil and even anthropogenic deposits. This process leads to a progressive alteration of the layer ending up in the decomposition of the vitric particles and ingrowth of clay minerals such as Kaolinite and Montmorillonite. Fur- ther research on possible chemical changes during transport in the stratosphere is presently being carried out.

\section{Acknowledgements}

The authors wish to express their sincerest thanks to all archaeologists and scientists who contributed pumice samples for this work, in particular M. Bietak (Univ. Vienna, Austria, samples from Tell el Dabca), M. Artzy (Univ. Haifa, Israel, samples from Tel Nami), W.-D. Niemeier (German Archaeological Institute in Athens, Greece, samples from Miletos), S. Wolff (Israel Antiquities Authority, Jerusalem) for samples from Megadim, Z. Herzog (Univ. Tel Aviv, Israel, pumice from Tel Gerisa), L.E. Stager (Harvard Semitic Museum, Cambridge MA, USA, samples from Ashkelon), F. Berti (Museo Archeologico Nazionale di Ferrara) and N. Momigliano (Univ. Bristol, United Kingdom, for generous cooperation during sampling at Iasos), P. Warren (Univ. Bristol, United Kingdom, pumice from Knossos), E.D. Oren (Ben Gurion University of the Negev, Beer-Sheva, Israel, samples from North Sinai). The research work is part of the project "Thera Ashes" carried out in the framework of the special research program SFB SCIEM 2000 "The Synchronisation of civilizations in the Eastern Mediterranean in the $2^{\text {nd }}$ Millennium B.C." and has been further supported by the Austrian chair for Archaeology of Israel in the Biblical Period and by the Austrian Friends of Tel Aviv University. 

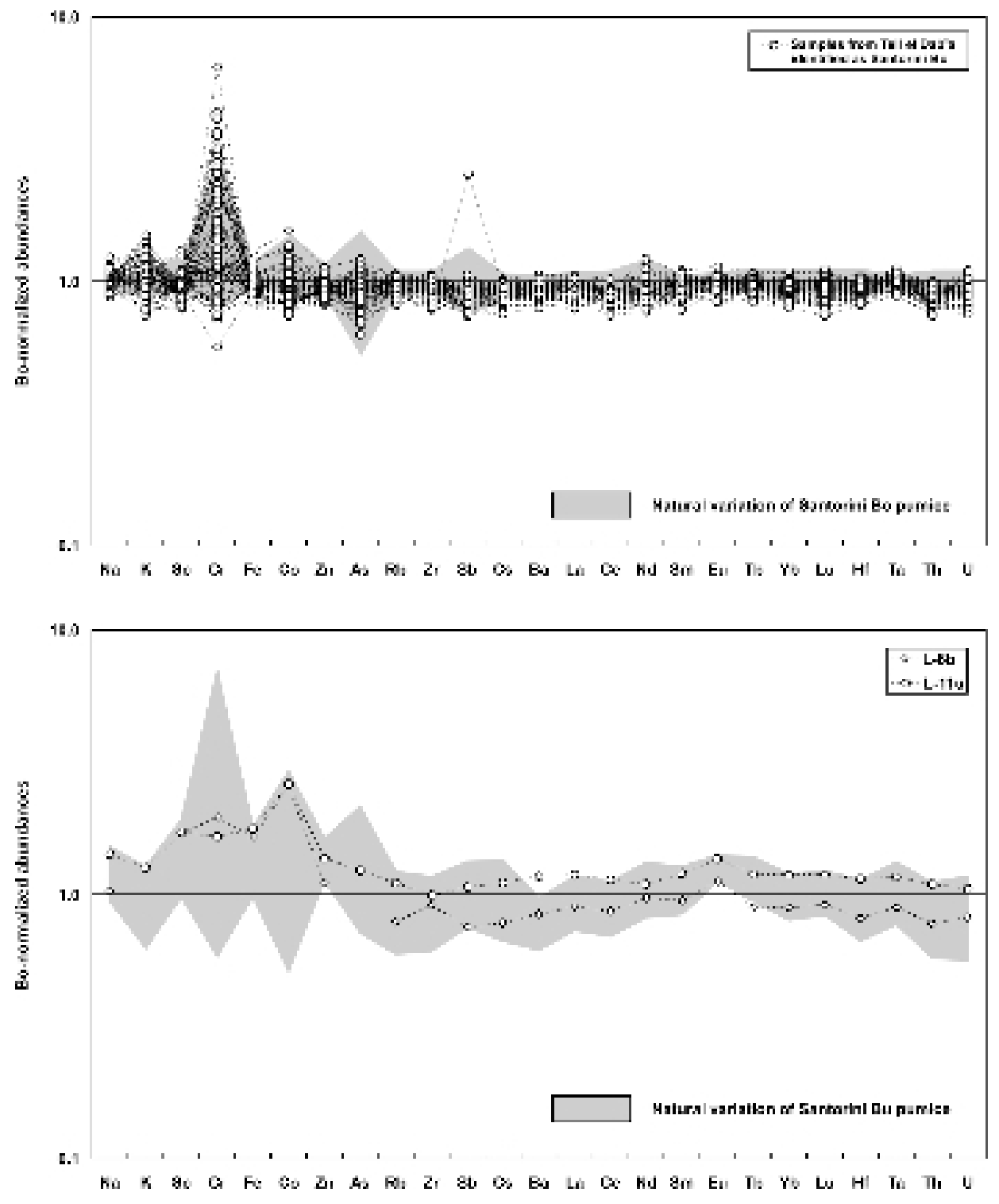

b)

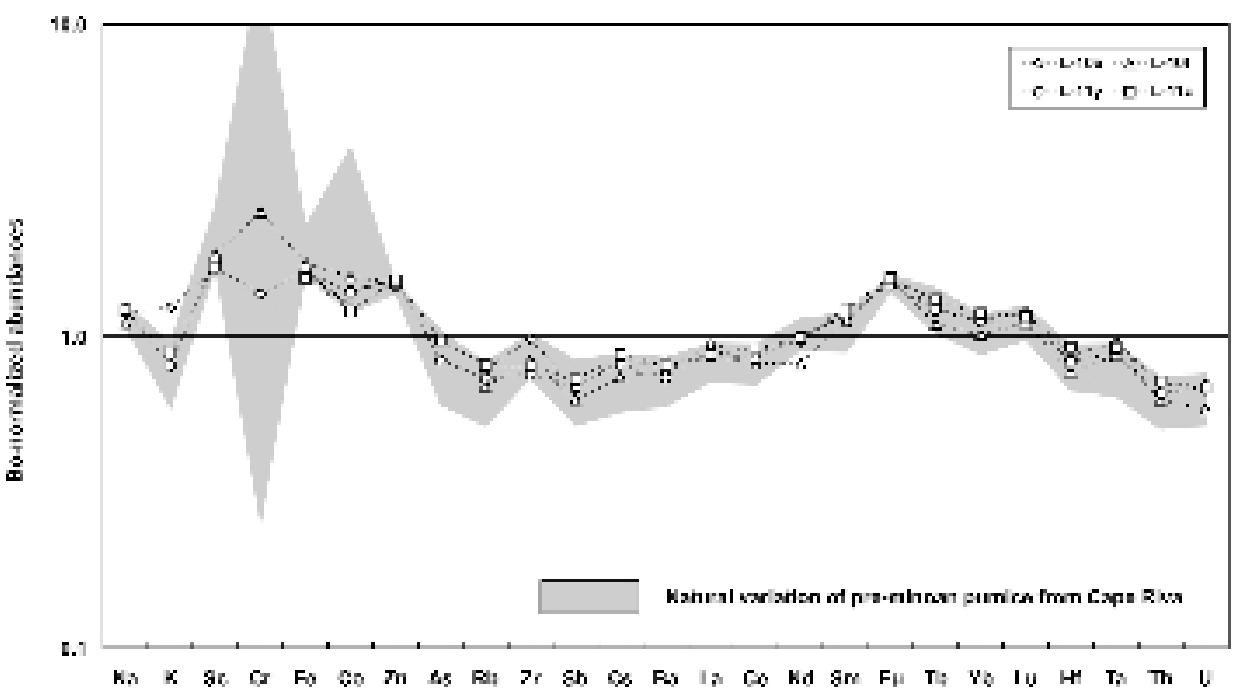

Fig. 3a-c Distribution of elements in pumice samples from Tell el Dabca, Series L. All values are normalized to the average Santorini Bo concentrations, see footnote 13. Shaded areas show the natural variation range of the original deposits - data from footnote 13 for a), from DumA B. (2002), Aktivierungsanalytische Untersuchung präminoischer Eruptivgesteine der Insel Thera (Santorini), Dipl. Thesis, Vienna Univ. of Technology, 194pp. for b) and c). 


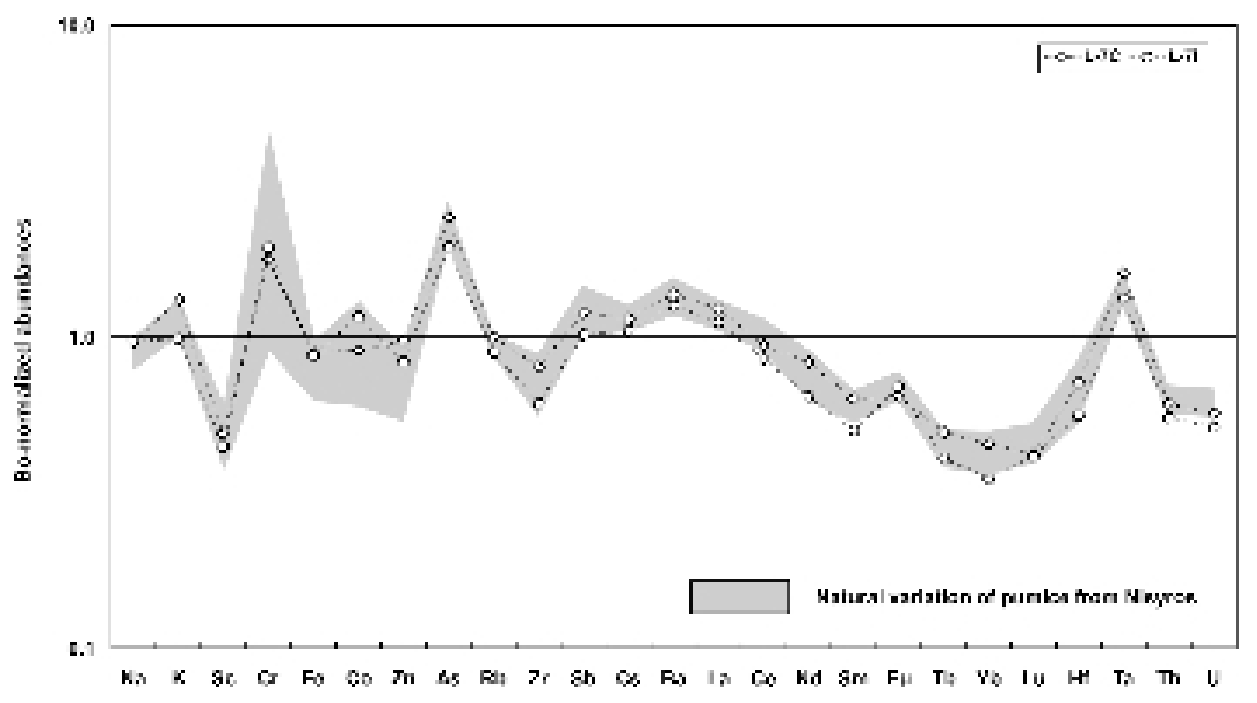

d)

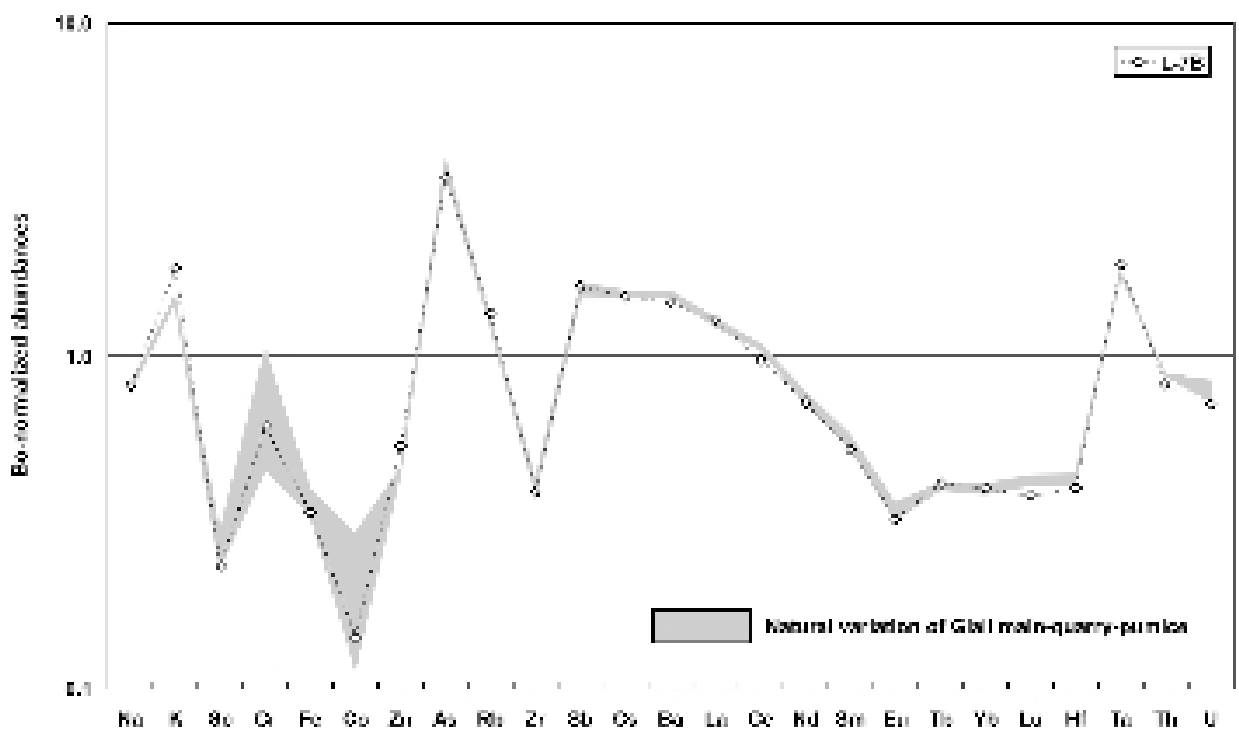

e)

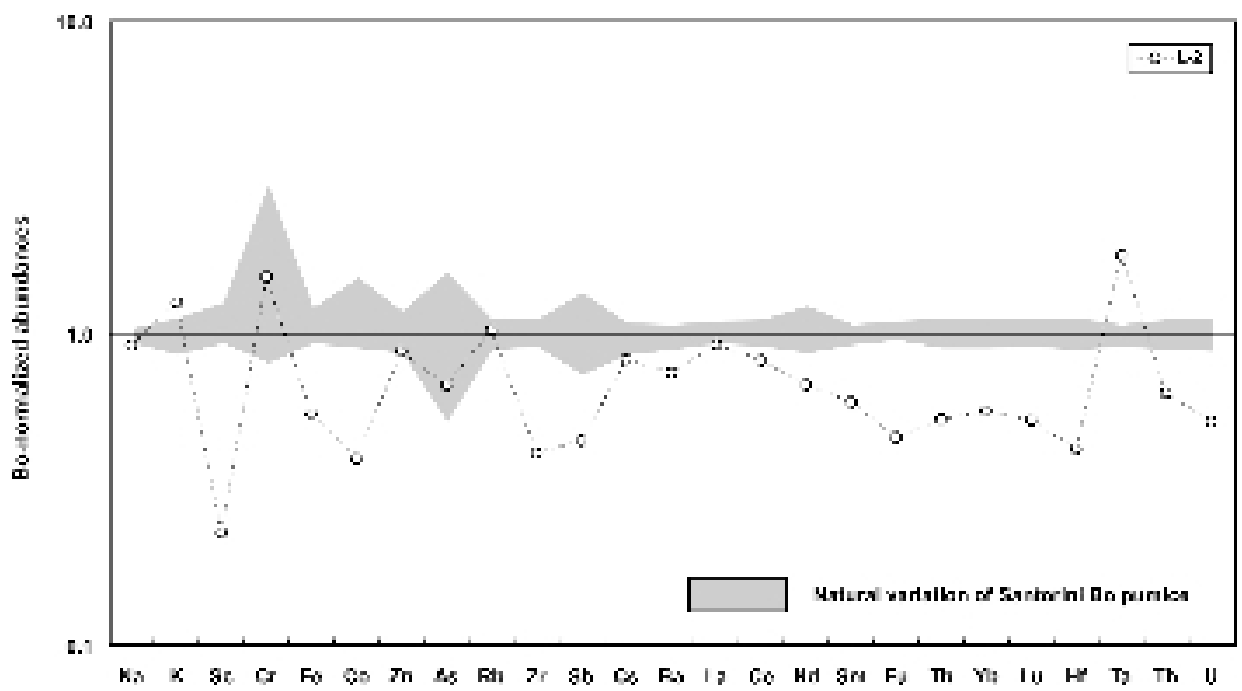

Fig. 3d-f Distribution of elements in pumice samples from Tell el Dab ${ }^{\mathrm{c}}$, Series L. All values are normalized to the average Santorini Bo concentrations, see footnote 13. Shaded areas show the natural variation range of the original deposits - data from footnote 13 for $\mathrm{d}$ ), e) and f). 


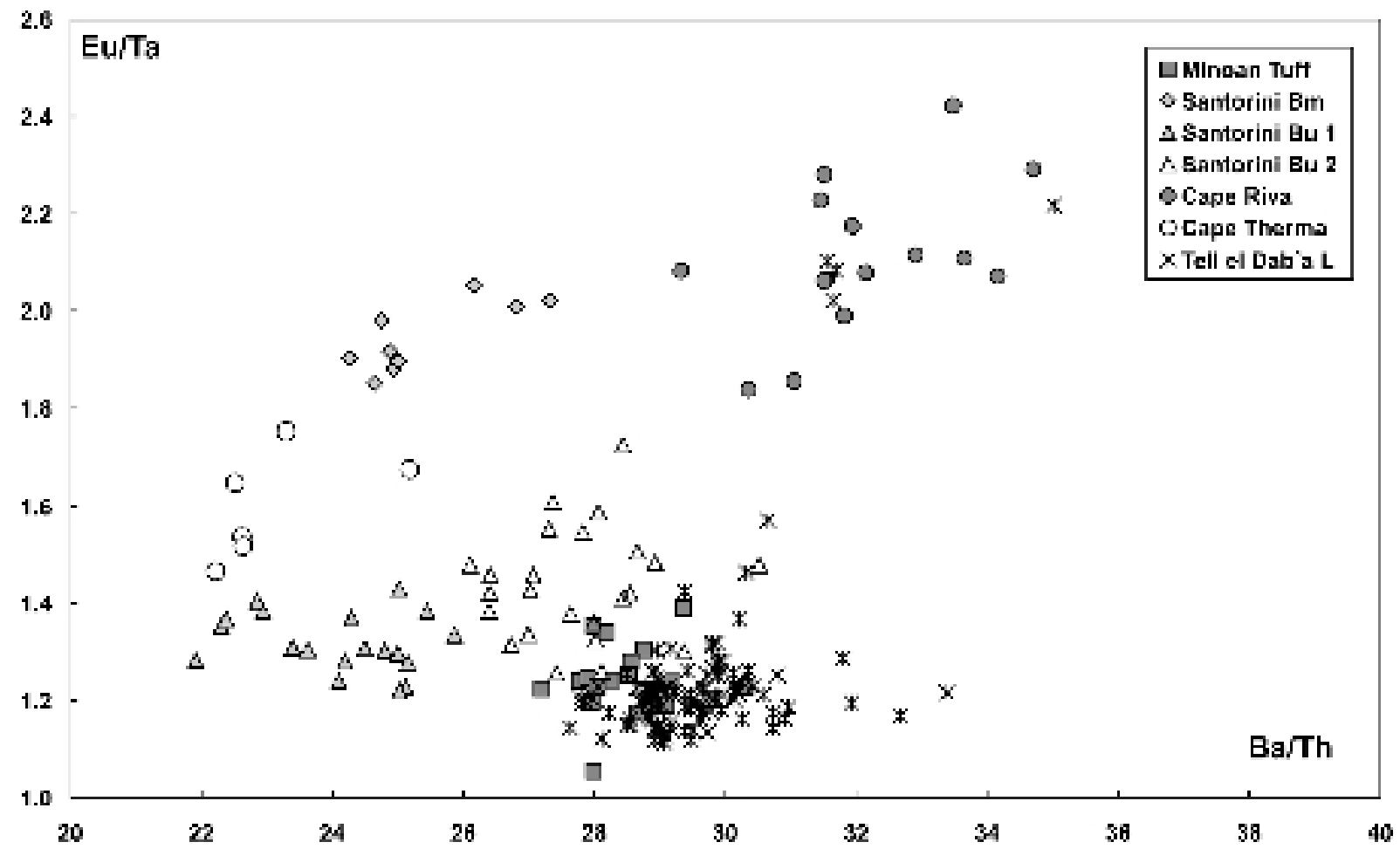

Fig. 4 Binary of trace element ratios for the differentiation of a pumice source within the Santorini volcanic complex

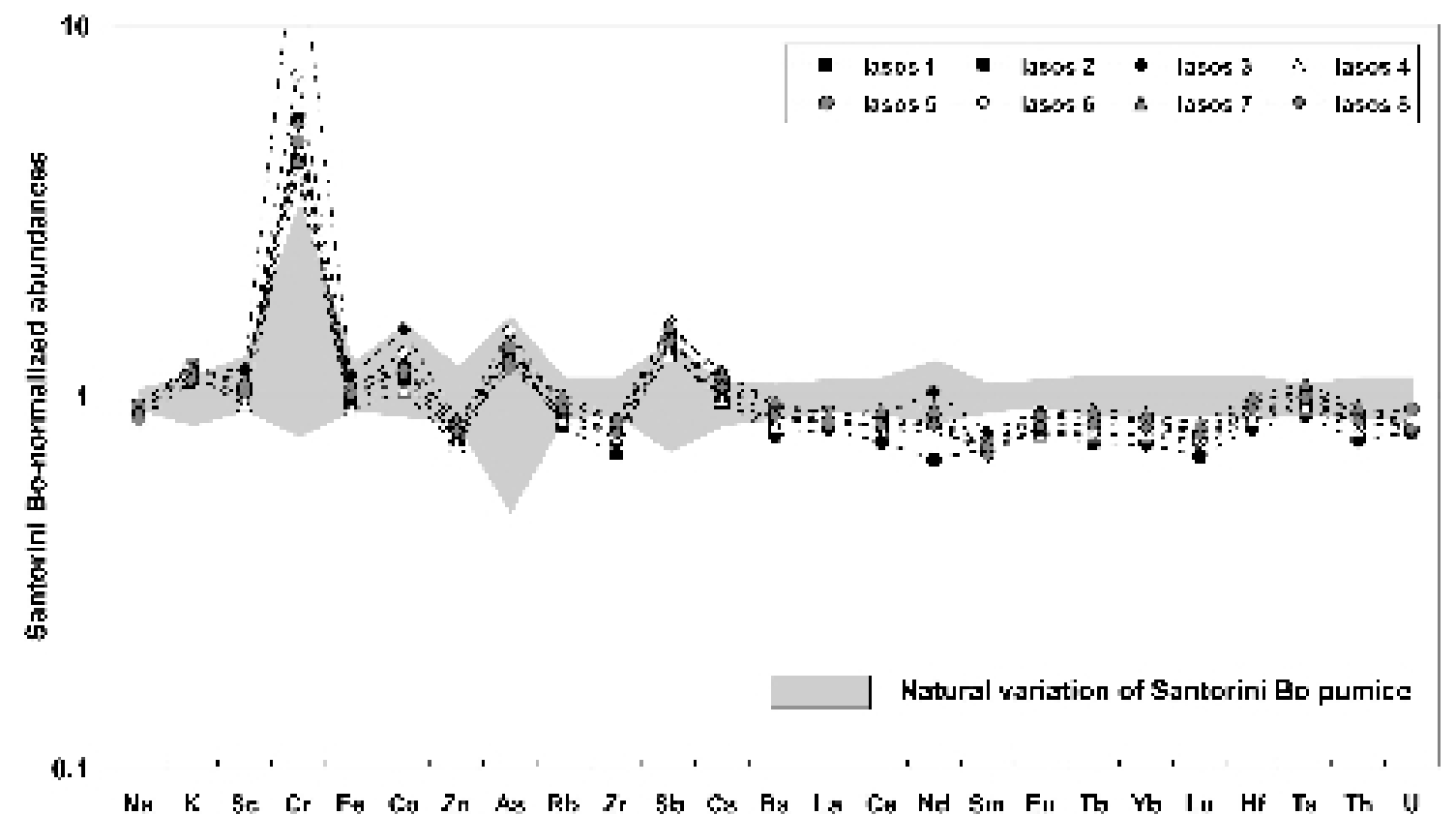

Fig. 5 Element distribution pattern for the tephra layer from Iasos. Normalization factors and natural variations from Footnote 13 

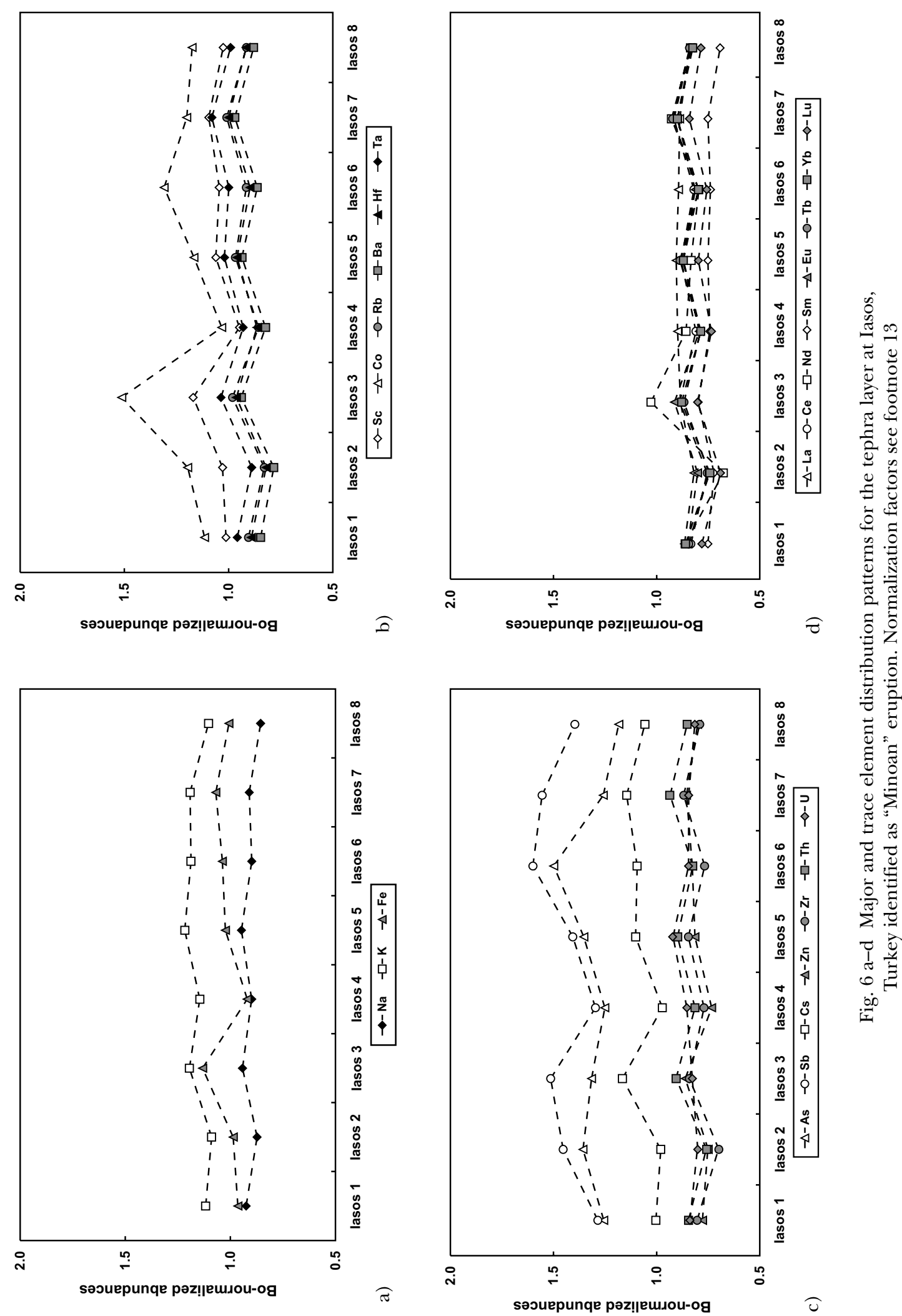


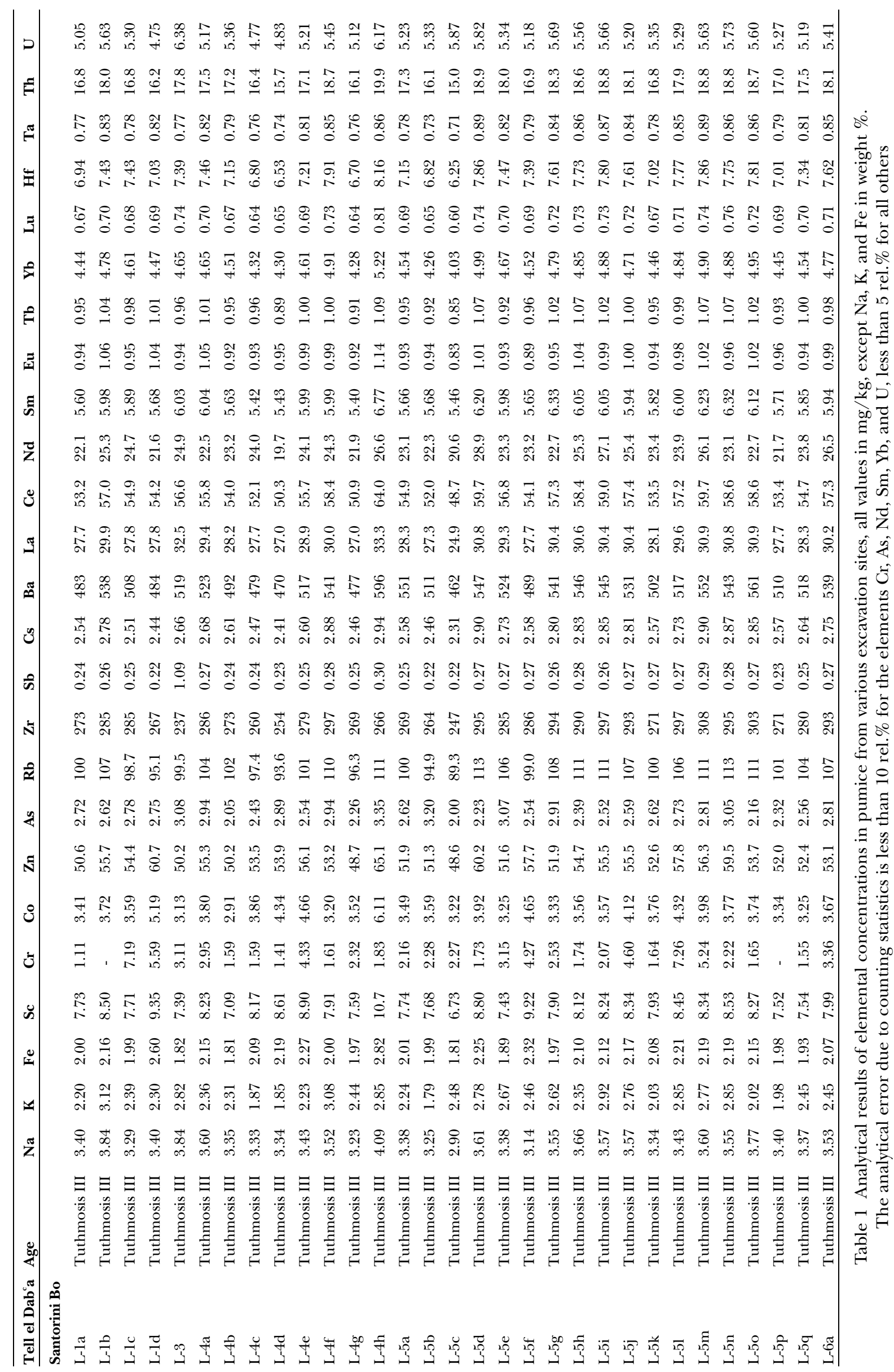




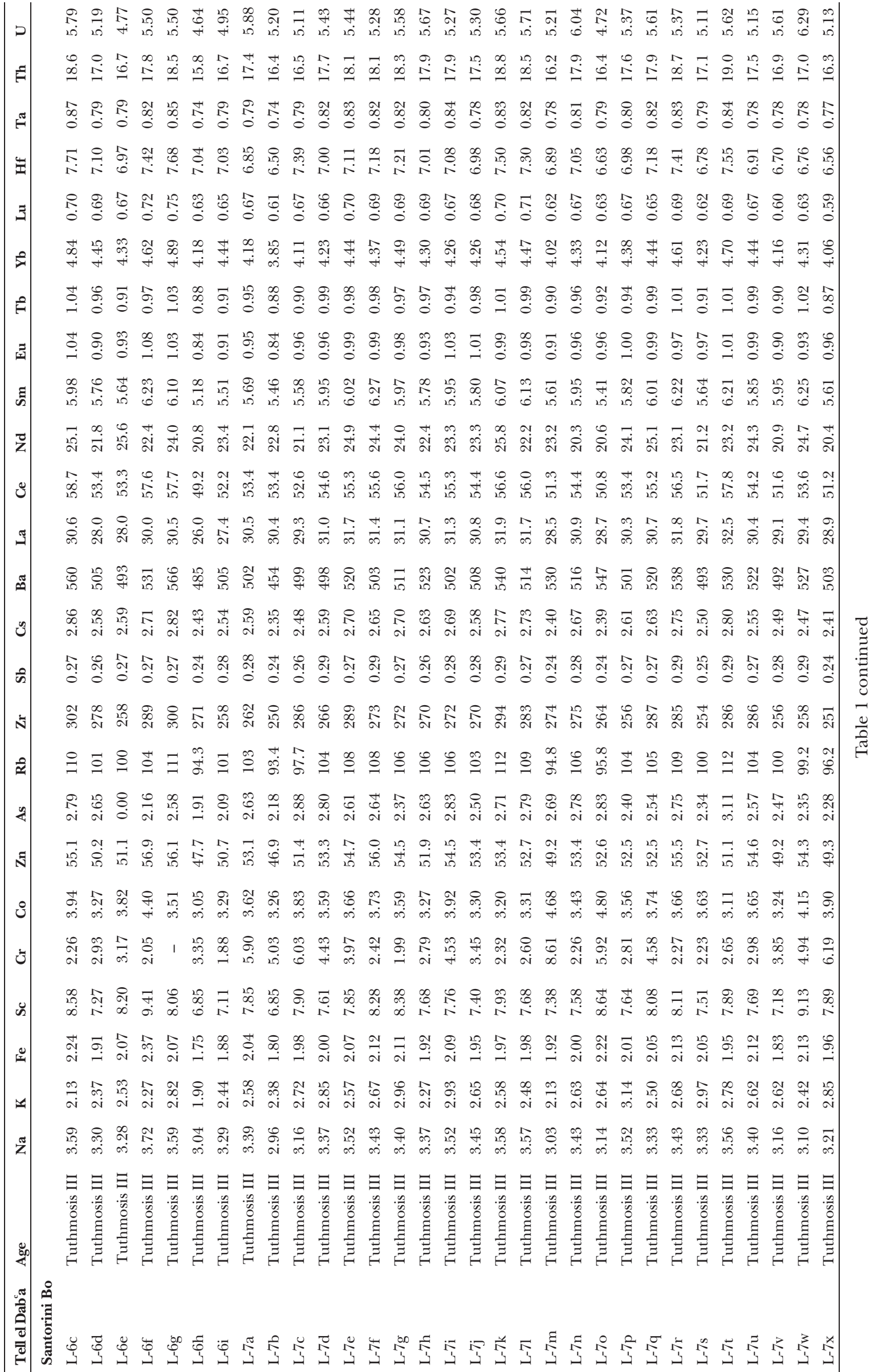




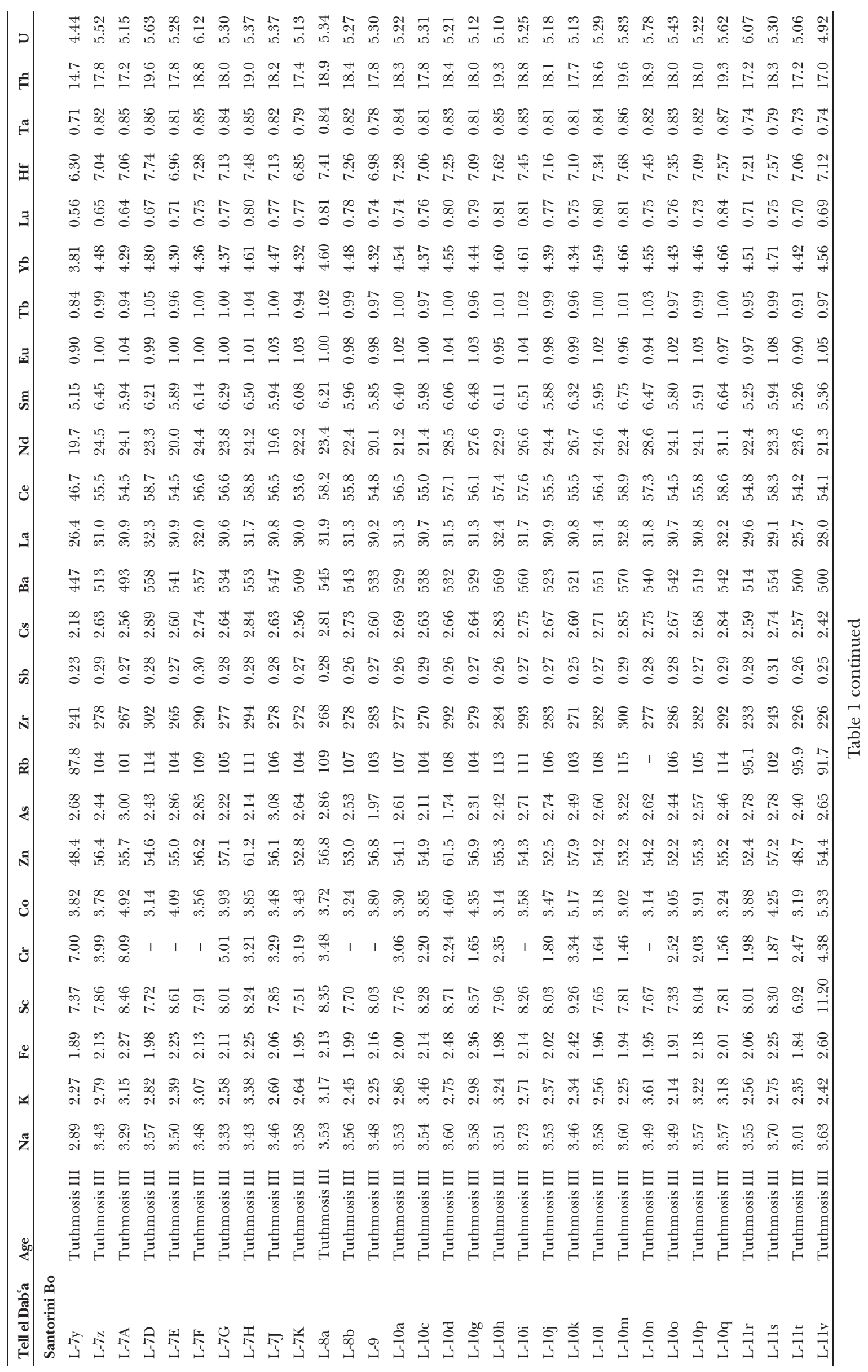




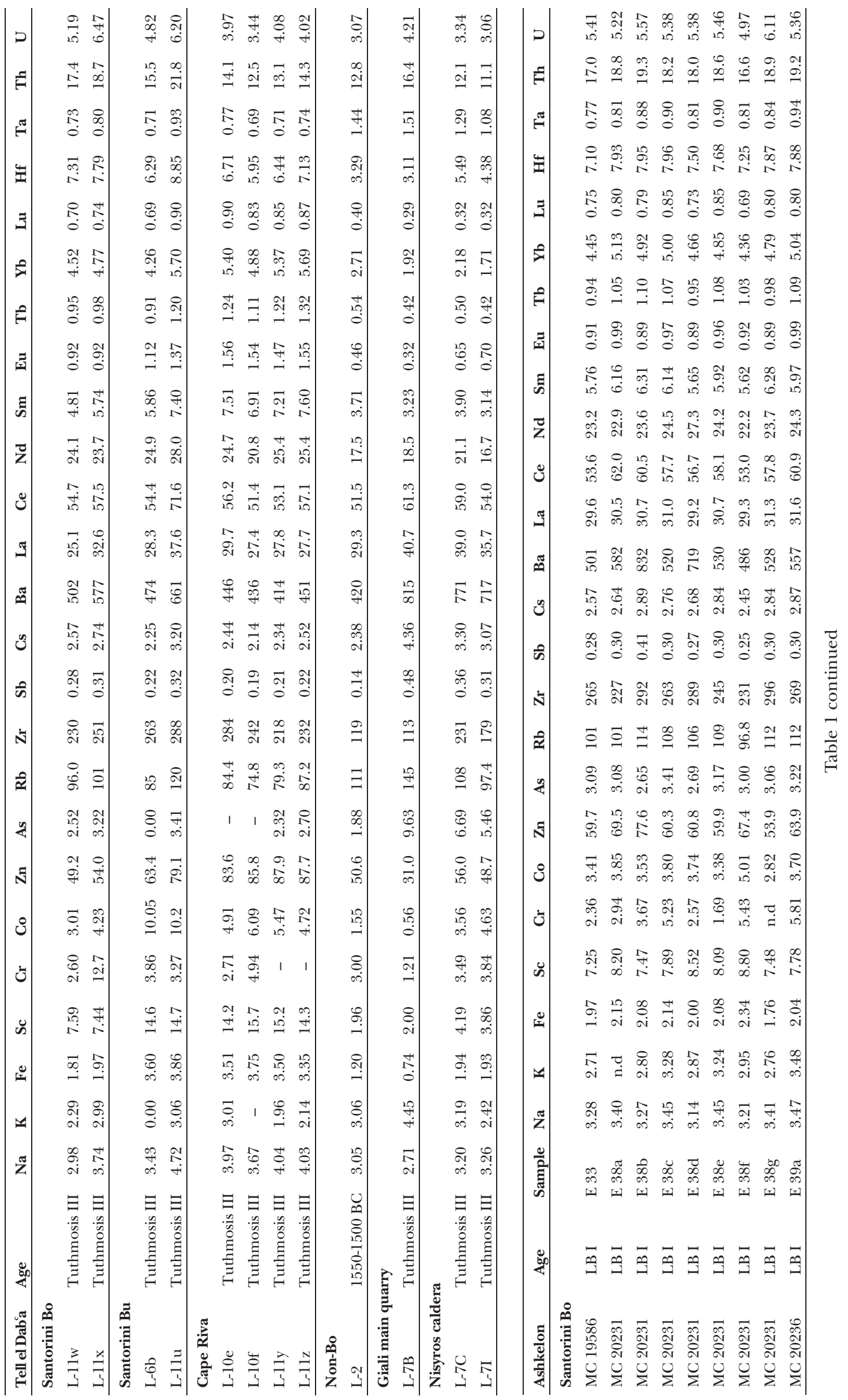




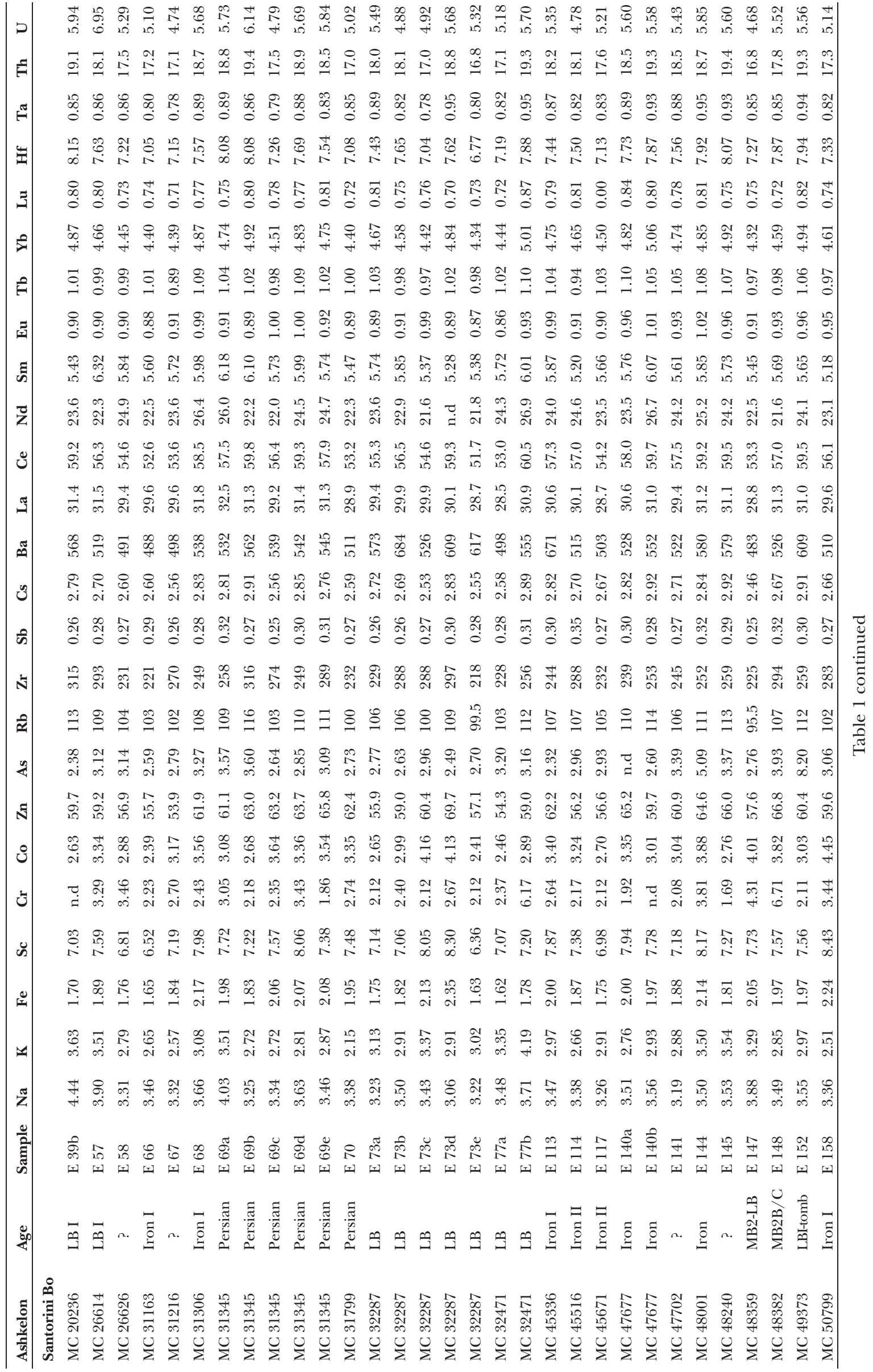




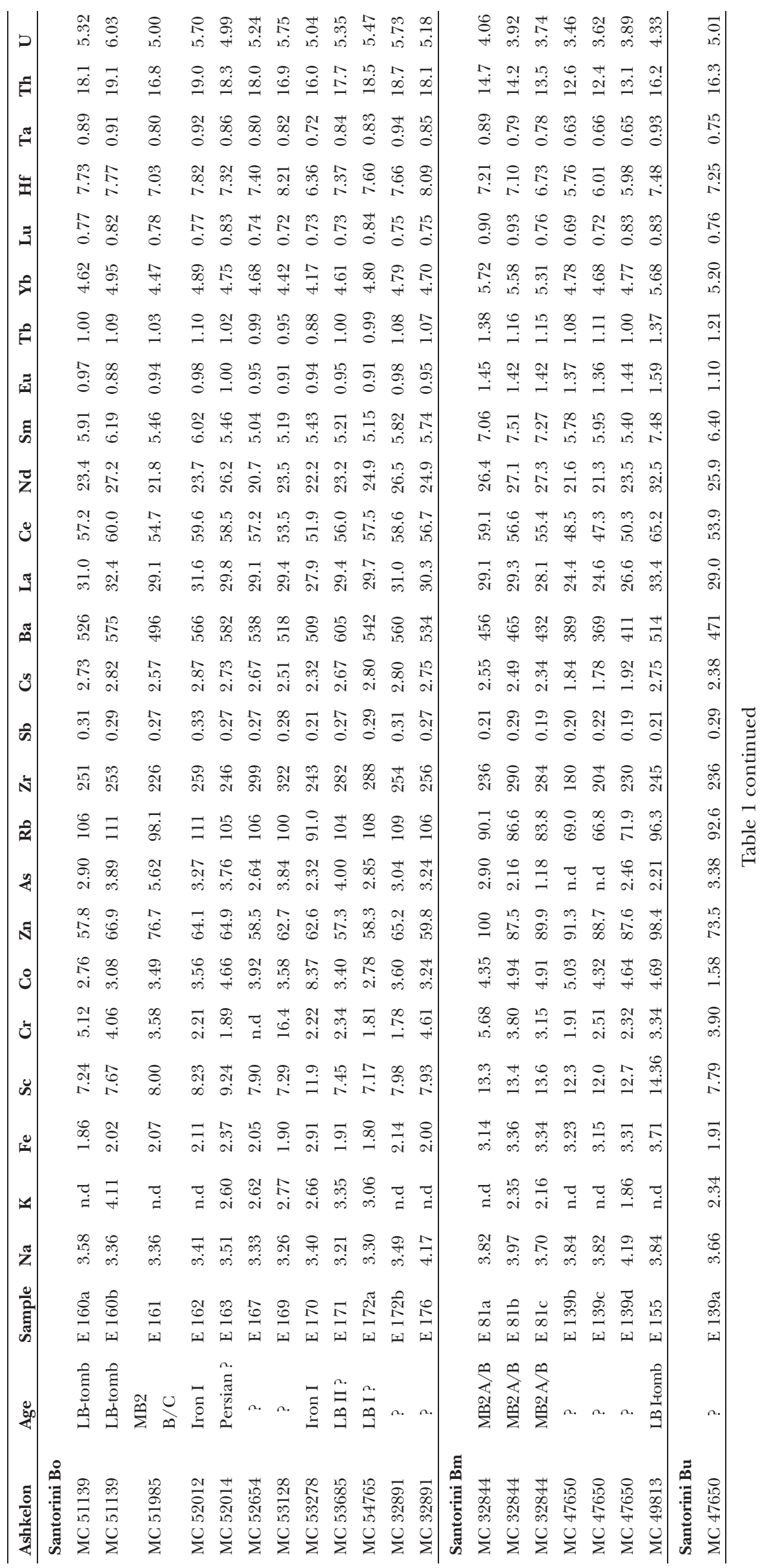




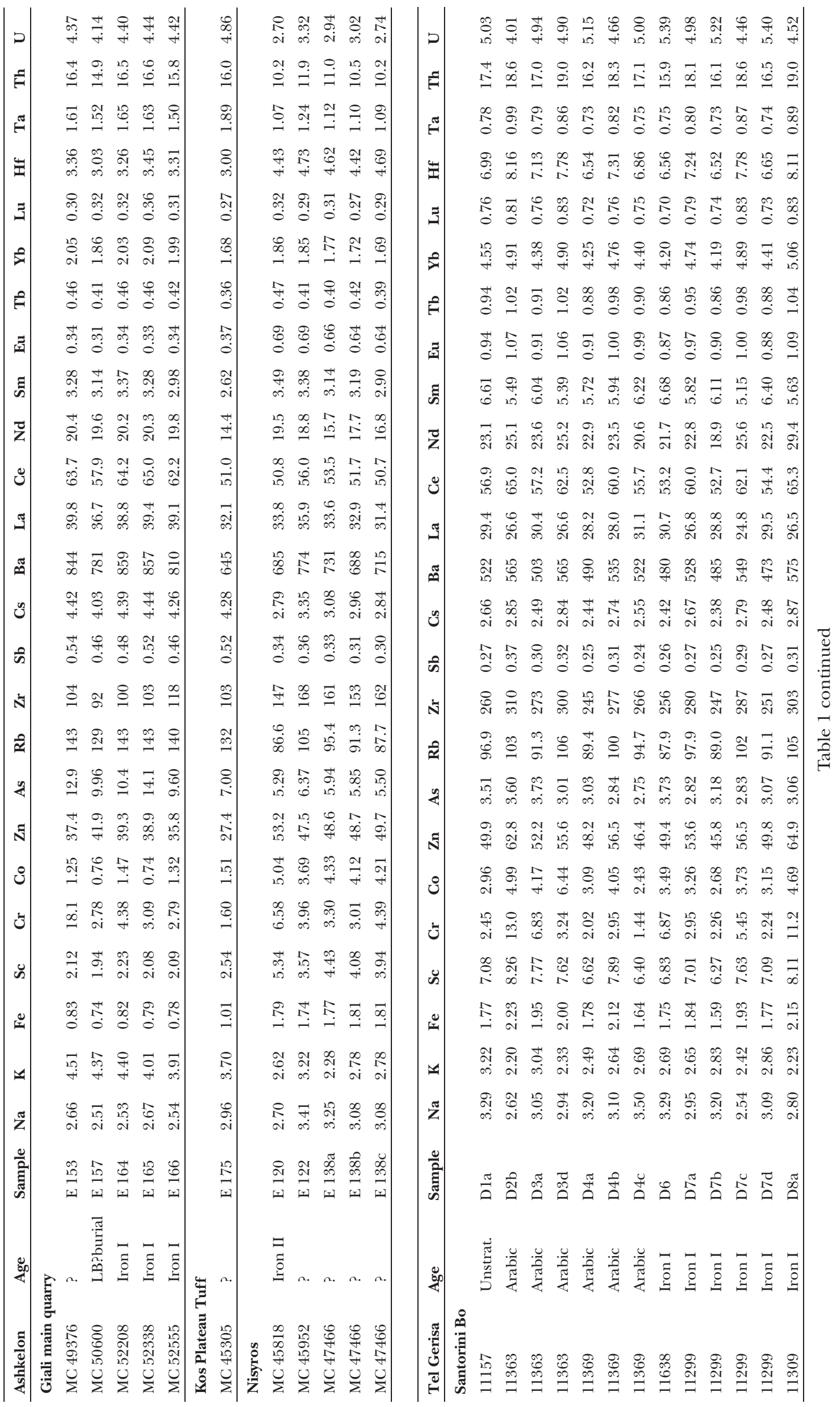




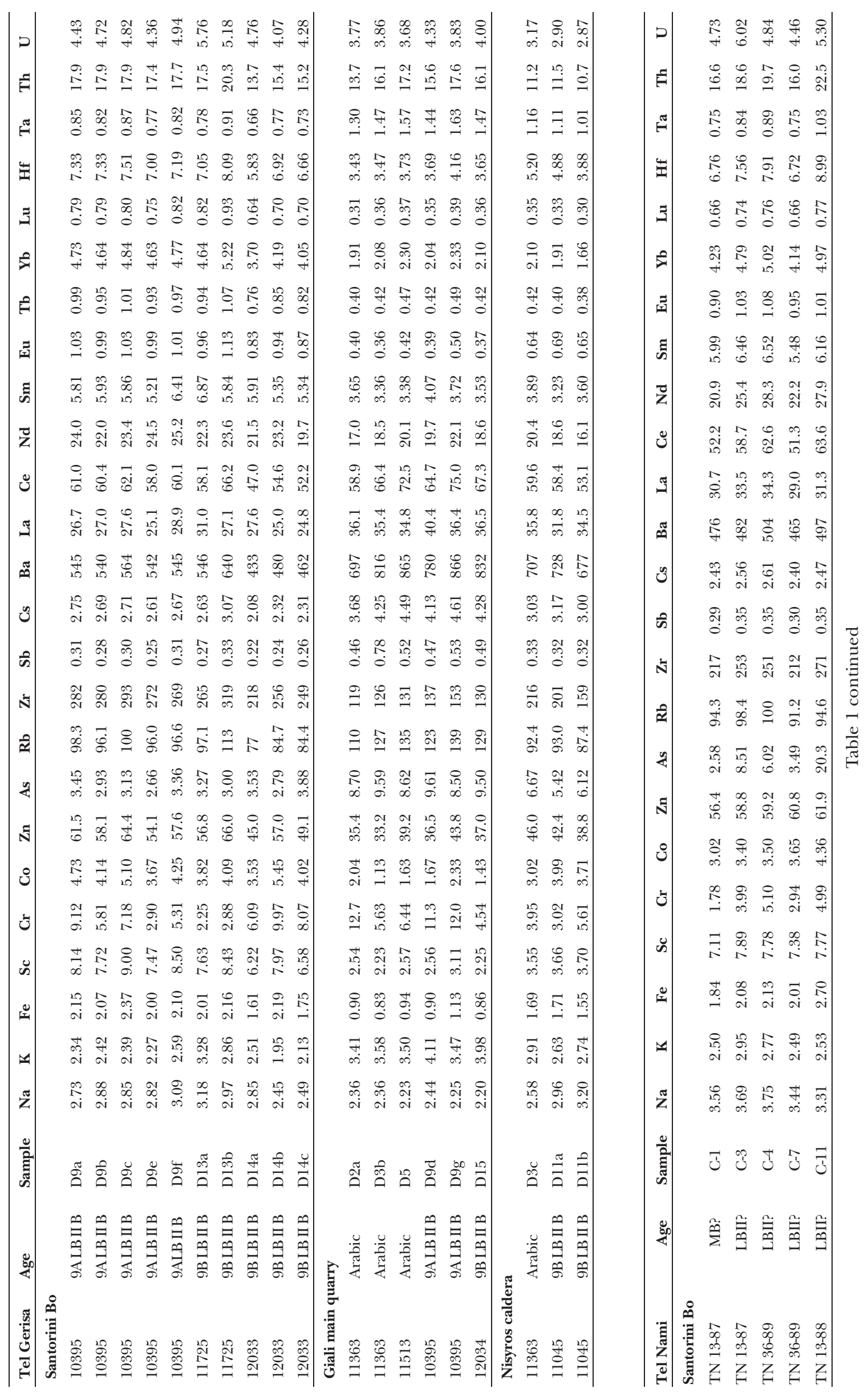




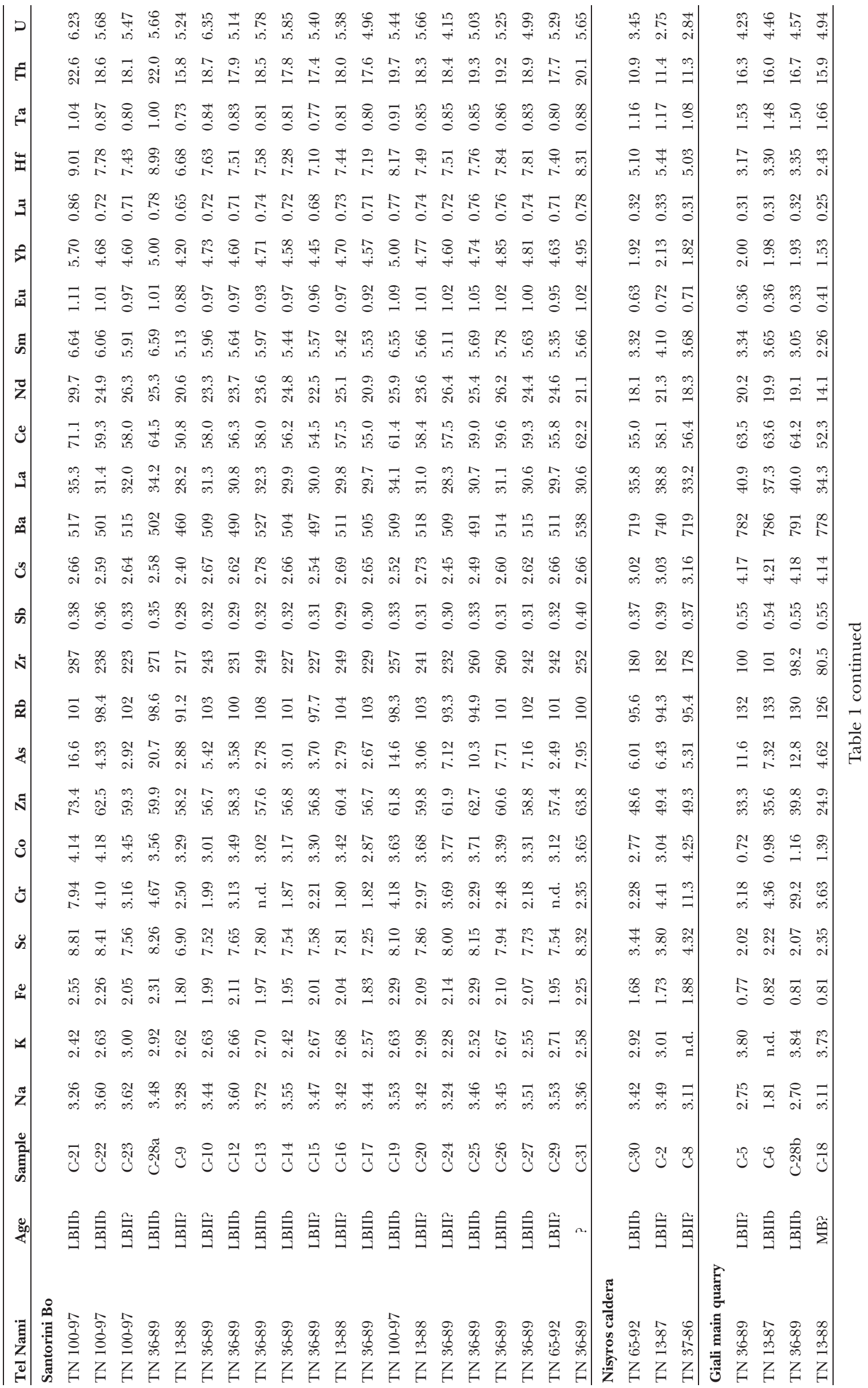




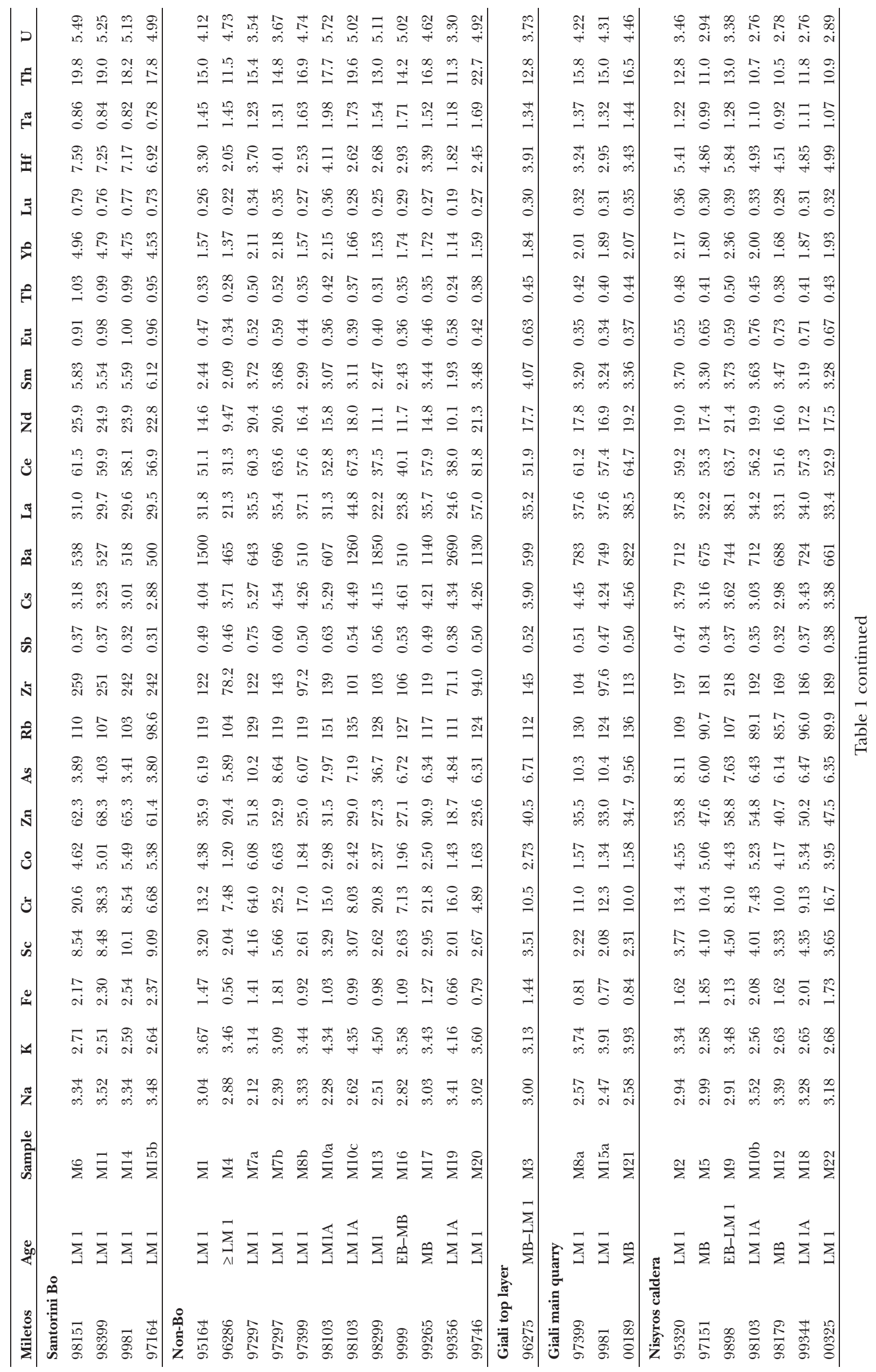




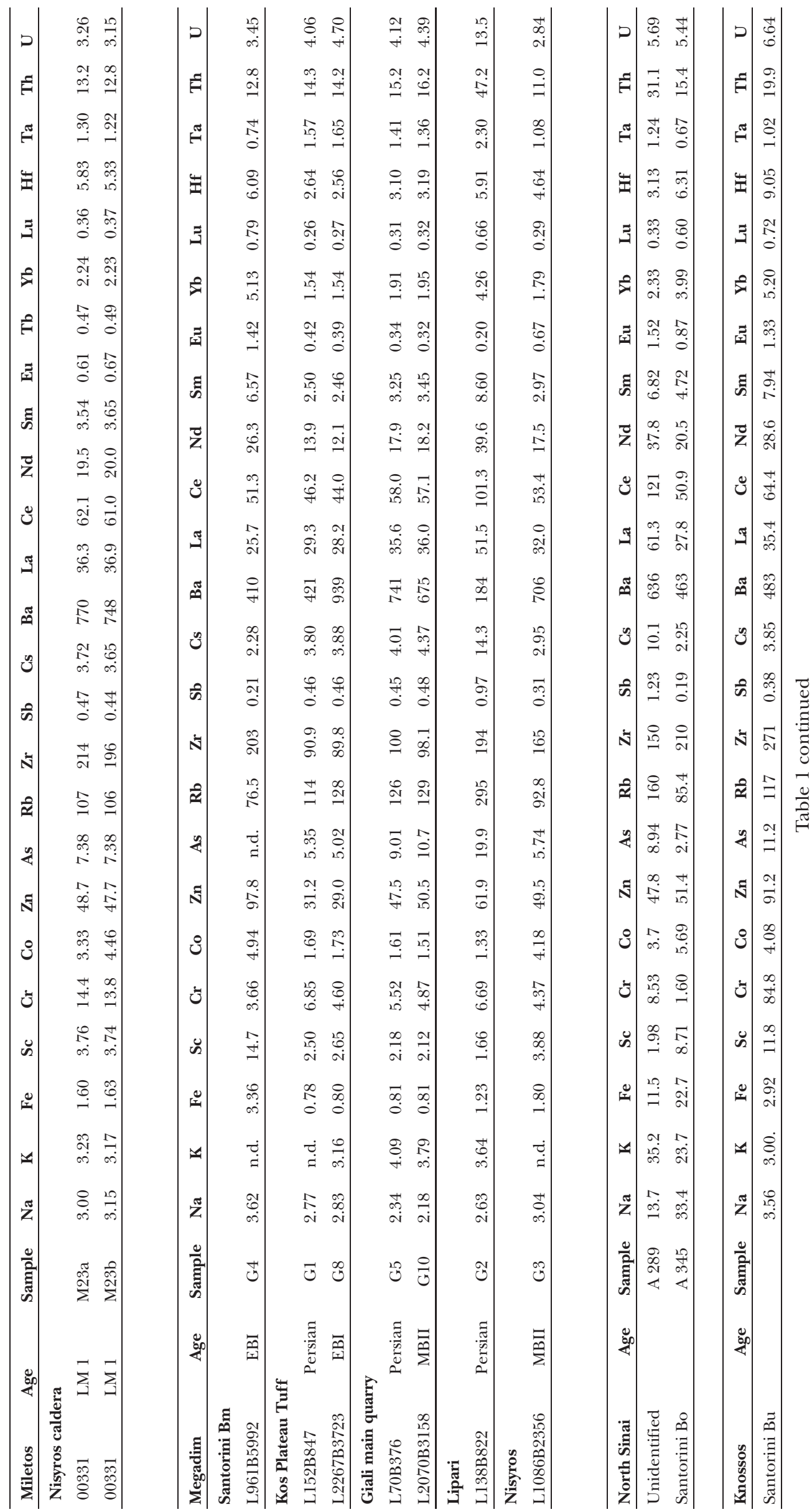




\begin{tabular}{|c|c|c|}
\hline Excavation site & Number & Provenance \\
\hline Tell el Dabca & 105 & 101 Santorini (95 Bo, 2 Bu, 4 Cape Riva), 2 Nisyros, 1 Giali, 1 non-Bo \\
\hline Ashkelon & 78 & 60 Santorini (52 Bo, 1 Bu, 7 Bm), 8 Giali, 1 Kos, 5 Nisyros, 4 non-Bo \\
\hline Tel Gerisa & 32 & 23 Santorini Bo, 6 Giali, 3 Nisyros \\
\hline Tel Nami & 32 & 25 Santorini Bo, 3 Nisyros, 1 Kos, 3 Giali \\
\hline Miletos & 29 & 4 Santorini Bo, 4 Giali, 9 Nisyros, 12 non-Bo \\
\hline Megadim & 7 & 1 Santorini Bm, 1 Nisyros, 2 Kos, 2 Giali, 1 Lipari \\
\hline North Sinai & 2 & 1 Santorini Bo, 1 non-Bo \\
\hline Knossos & 1 & 1 Santorini Bu \\
\hline
\end{tabular}

Table 2 Compilation of identified pumice samples. The unidentified samples are most likely of Anatolian origin Bo ... oberer Bimsstein (Minoan Tuff), Bm... Middle Tuff Sequence, Bu ... unterer Bimsstein (Lower Pumice Tuff); non-Bo ... unidentified, but definetly of non-Minoan origin

\begin{tabular}{|c|c|c|}
\hline Eruption & Age $[\mathrm{ky}]$ & Reference \\
\hline Santorini Cape Therma & $257 \pm 31$ & DRUITT et al (1999) \\
\hline Santorini Lower Pumice (Bu) & $180-205$ & DRUITT et al (1999) \\
\hline Kos Plateau Tuff & 145 & KELLER et al (1990) \\
\hline Santorini Middle Tuff (Bm) & 100 & DruitT et al (1999) \\
\hline Santorini Cape Riva & 21 & DRUITT et al (1999) \\
\hline Giali main quarry & $\geq$ age of Nisyros & KELLER et al (1990) \\
\hline Nisyros caldera & $>12.5$ & KELLER et al (1990) \\
\hline Giali top layer & $<$ age of Nisyros & KELLER et al (1990) \\
\hline Lipari Mt. Pilato & $\sim 5$ & Pichler (1981) \\
\hline Santorini Minoan Tuff (Bo) & $\sim 3.6$ & FrIEDRICH et al (1990) \\
\hline
\end{tabular}

Table 3 Compilation of volcanic eruption ages associated with pumiceous deposits

Druitt T.H., Edwards L., Mellors R.M., Pyle D.M., Sparks R.S.J., LanPhere M., Davies M., Barriero B. (1999), Santorini volcano. Geological Society Special Publication, Geological Society of London 19, $165 \mathrm{pp}$. Keller J., Rehren Th., Stadlbauer E. (1990), Explosive Volcanism in the Hellenic arc: a summary and a review, in: Hardy D.A., Renfrew A.C. (eds.), Thera and the Aegean World III, Vol. 2, 13-26. PICHLER H. (1981), Italienische Vulkan-Gebiete III, Gebr. Bornträger, Berlin-Stuttgart, 20 pp. Friedrich W.L., WAGNer P., TAUBER H. (1990), Radiocarbon dated plant remains from the Akrotiri excavation on Santorini, Greece, in: Hardy D.A., ReNFrew A.C. (eds.), Thera and the Aegean World III, Vol. 3, 188-196. 


\begin{tabular}{lccccccccccccc}
\hline Sample & $\begin{array}{c}\text { Na } \\
\text { [wt.\%] }\end{array}$ & $\begin{array}{c}\text { K } \\
\text { [wt.\%] }\end{array}$ & $\begin{array}{c}\text { Fe } \\
{[\mathbf{w t . \%} \text { ] }}\end{array}$ & $\begin{array}{c}\text { Decarb } \\
{[\mathbf{w t . \%}]}\end{array}$ & Sc & Cr & Co & Zn & As & Rb & Zr & Sb & Cs \\
\hline Iasos 1 & 3.079 & 2.715 & 2.106 & 6.27 & 8.68 & 8.38 & 4.38 & 54.0 & 3.48 & 97.9 & 233 & 0.38 & 2.90 \\
Iasos 2 & 2.906 & 2.646 & 2.155 & 5.72 & 8.82 & 11.1 & 4.71 & 52.2 & 3.76 & 89.7 & 203 & 0.43 & 2.84 \\
Iasos 3 & 3.136 & 2.903 & 2.473 & 4.71 & 10.0 & 37.2 & 5.95 & 59.9 & 3.65 & 106 & 244 & 0.45 & 3.37 \\
Iasos 4 & 2.992 & 2.783 & 2.009 & 9.86 & 8.13 & 7.77 & 4.06 & 51.0 & 3.47 & 92.8 & 224 & 0.39 & 2.81 \\
Iasos 5 & 3.153 & 2.956 & 2.236 & 6.13 & 9.10 & 9.60 & 4.59 & 56.6 & 3.75 & 105 & 246 & 0.42 & 3.19 \\
Iasos 6 & 2.989 & 2.885 & 2.267 & 9.24 & 8.96 & 14.5 & 5.15 & 57.5 & 4.16 & 99.0 & 223 & 0.48 & 3.17 \\
Iasos 7 & 3.030 & 2.894 & 2.335 & 7.02 & 9.39 & 8.55 & 4.72 & 59.5 & 3.49 & 109.2 & 252 & 0.46 & 3.31 \\
Iasos 8 & 2.849 & 2.681 & 2.199 & 11.6 & 8.80 & 10.6 & 4.62 & 55.8 & 3.28 & 99.0 & 230 & 0.42 & 3.06 \\
Iasos 1f & 1.749 & 3.169 & 2.329 & 43.6 & 12.2 & 15.8 & 4.92 & 56.8 & 7.12 & 95.7 & 227 & 1.18 & 4.15 \\
\hline
\end{tabular}

All concentrations in $\mathrm{mg} / \mathrm{kg}$, except as noted

\begin{tabular}{|c|c|c|c|c|c|c|c|c|c|c|c|c|c|}
\hline Sample & $\mathbf{B a}$ & $\mathbf{L a}$ & Ce & Nd & $\mathrm{Sm}$ & $\mathbf{E u}$ & $\mathrm{Tb}$ & $\mathbf{Y b}$ & $\mathbf{L u}$ & Hf & Ta & Th & $\mathbf{U}$ \\
\hline Iasos 1 & 477 & 27.4 & 52.5 & 22.1 & 4.64 & 0.85 & 0.85 & 4.35 & 0.65 & 6.90 & 0.77 & 16.9 & 4.96 \\
\hline Iasos 2 & 442 & 26.0 & 47.5 & 17.4 & 4.46 & 0.80 & 0.76 & 3.75 & 0.57 & 6.35 & 0.71 & 15.2 & 4.74 \\
\hline Iasos 3 & 529 & 28.1 & 55.9 & 26.4 & 4.93 & 0.92 & 0.88 & 4.44 & 0.66 & 7.46 & 0.83 & 18.1 & 4.90 \\
\hline Iasos 4 & 464 & 28.5 & 51.0 & 22.0 & 4.59 & 0.79 & 0.80 & 3.98 & 0.61 & 6.69 & 0.75 & 16.3 & 5.05 \\
\hline Iasos 5 & 527 & 28.7 & 55.5 & 21.4 & 4.64 & 0.87 & 0.90 & 4.40 & 0.66 & 7.43 & 0.82 & 18.0 & 5.45 \\
\hline Iasos 6 & 486 & 28.4 & 51.6 & 20.4 & 4.56 & 0.81 & 0.81 & 4.03 & 0.63 & 6.95 & 0.80 & 16.5 & 5.01 \\
\hline Iasos 7 & 547 & 28.2 & 57.7 & 23.8 & 4.64 & 0.90 & 0.93 & 4.55 & 0.70 & 7.74 & 0.87 & 18.7 & 5.00 \\
\hline Iasos 8 & 496 & 26.6 & 52.7 & 21.4 & 4.28 & 0.83 & 0.85 & 4.17 & 0.65 & 7.10 & 0.80 & 17.0 & 4.83 \\
\hline Iasos 1f & 128 & 24.8 & 46.4 & 16.7 & 4.74 & 0.66 & 0.72 & 3.77 & 0.59 & 7.26 & 0.82 & 19.5 & 5.00 \\
\hline
\end{tabular}

All concentrations in $\mathrm{mg} / \mathrm{kg}$

Table 4 Major and trace element contents of eight sub-units from the tephra-layer at Iasos.

"Decarb" designates the amount removed by the decarbonatization and purification process 
